\title{
Transposition
}

Musique et Sciences Sociales

\section{"The Orchestra, in its Sounds, Defies Virtue...": The Role of the Erotic in the Works of Massenet.}

\section{Annegret Fauser}

Translator. Maggie Jones

\section{OpenEdition}

Journals

\section{Electronic version}

URL: http://journals.openedition.org/transposition/6494

DOI: 10.4000/transposition.6494

ISSN: 2110-6134

Publisher

CRAL - Centre de recherche sur les arts et le langage

\section{Electronic reference}

Annegret Fauser, "'The Orchestra, in its Sounds, Defies Virtue...": The Role of the Erotic in the Works of Massenet.", Transposition [Online], 9 | 2021, Online since 30 March 2021, connection on 23 April 2021. URL: http://journals.openedition.org/transposition/6494; DOI: https://doi.org/10.4000/transposition. 6494

This text was automatically generated on 23 April 2021.

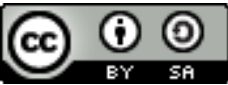

La revue Transposition est mise à disposition selon les termes de la Licence Creative Commons Attribution - Partage dans les Mêmes Conditions 4.0 International. 


\title{
"The Orchestra, in its Sounds, Defies Virtue...": The Role of the Erotic in the Works of Massenet.
}

\author{
Annegret Fauser
}

Translation : Maggie Jones

\section{EDITOR'S NOTE}

Originally published in French in Massenet en son temps, edited by Patrick Gillis and Gérard Condé, Saint-Étienne : Association du Festival Massenet, 1999, p. 156-179. Translated from the French in 2021; English translations of citations herein are our own.

"The orchestra, in its sounds, defies virtue..."

(Bellaigue)

"Familiarizing the ear to pleasure predisposes to all pleasures-yes, all!" (Boylesve, La Jeune Fille

bien élevée, 1909)

In 1897, in his book Massenet. Étude critique et documentaire, Eugène de Solenière characterised Massenet's music as follows:

A yonic scent drifts over his entire output and, one can boldly assert, it will always do so. The master of excitations, he will perhaps invent new intoxications, and it is possible that he (who, more than anyone, has lent credence to the saying that music is a masturbation of the ear) will manage to mate sounds and rape harmonies in a manner so new, so persuasive, that it will give birth to a hitherto unknown kind of jouissance, the je ne sais quoi of a quintessential Kama Sutra, that will engender the Gospel of the flesh, the supreme prayer to Venus. But whether he creates anew or repeats himself, progresses or declines, it will always and indefinitely be for and by the flesh. ${ }^{1}$ 
2 In these lines full of violence are concentrated almost all of the issues that Massenet's contemporaries connected with the role of the erotic in his work, that is, decadence, the influence of Wagner, the complex relationship between religion and eroticism, and the problems of a bourgeois world trying to develop strategies for approaching music that transgressed its social laws. In Solenière's view, this modern music, aimed "to give sensations" rather than "truly to move" the emotions, and replaced "chaste and healthy passion" with a "frenzy of the senses". ${ }^{2}$ He cites Verlaine and Baudelaire as parallel phenomena in literature, but as for Massenet, "No living artist represents, in all respects, French modernism so well". ${ }^{3}$

3 At the time that Solenière wrote this text, the three operas by Massenet which were considered his most erotic had already been performed: Hérodiade in Brussels in 1881; and in Paris, Esclarmonde in 1889 at the Opéra-Comique, and Thaïs at the Palais Garnier in 1894. For Hérodiade and Thais, their erotic character is due primarily to the subject matter, whereas it was the music that gave Esclarmonde this reputation. The difference between Hérodiade and Thaïs, on the one hand, and Esclarmonde on the other, lies in two key points: Hérodiade and Thaïs are essentially about feminine seduction - to varying degrees professional and destructive - and for this, Massenet employs the musical devices traditionally associated with women's powers of seduction, that is, seductive dancing and singing, as they appear in Carmen, for example. ${ }^{4}$ The opera Esclarmonde, on the other hand, explores not so much the theme of seduction as the erotic relationships between the three main characters - father, daughter, lover - and its musical devices were considered highly unusual in the Paris of 1889 . The familiar objection that, in this context as well, Wagner's music was more ahead of its time than that of his French contemporaries can only partly be substantiated. As the programmes of operas and concerts in Paris at the time reveal, those of Wagner's works considered most erotic such as the music of the Venusberg and Act II of Tristan - were only rarely performed in public. ${ }^{5}$ To the ears of critics at the time, the music of Esclarmonde sounded totally novel, and especially the interlude between the third and fourth tableaux (in the middle of Act II).

Its expressive intensity is extraordinary, and I do not think that anyone has ever

taken this far the art of saying absolutely everything through sound. ${ }^{6}$

In the case of Esclarmonde, the combination of evocative music, a libretto teeming with erotic allusions, a bourgeois constellation of characters, ${ }^{7}$ and strong reactions in the press make this opera ideal as a case study on the role of eroticism not only in Massenet's work, but also in Parisian society of the late 1880 s.

5 Esclarmonde is the story of a daughter (Esclarmonde) to whom her father (Phorcas) turns over the ruling of his empire as he himself retreats into a forest. Like her father, she possesses magical powers. The only condition for this transfer of power is that she must remain veiled until she reaches the age of majority, at which time a tournament will determine her future husband, who shall become the new emperor of Byzantium. As the opera unfolds, Esclarmonde learns that the man she secretly loves (Roland) is about to be married. She uses her magic powers to bring Roland to an enchanted island where, after he is sworn to secrecy, they spend a night of passion. The city of Blois comes under attack by the Saracens, and Esclarmonde dispatches Roland, armed with a magic sword, to save his country. He is victorious, and the King of France offers him his daughter's hand in marriage. Roland declines, claiming a reason he cannot reveal, but the Bishop of Blois manages to wrench the secret from him and learns of Esclarmonde's 
nightly visits to Roland. At midnight, the bishop catches the two lovers unaware and unveils Esclarmonde. This betrayal ends their union, and Esclarmonde is taken away and kept hidden by spirits. Worried when she does not return to the palace, Esclarmonde's sister and guardian (Parséis) informs their father. He orders the spirits to bring Esclarmonde to him and, learning of her "crime", he punishes her: she loses her beloved and all of her magic powers. Roland, hearing from Esclarmonde herself that their romance is over, decides to seek death in battle. He enters the tournament in Byzantium and, as the victor, wins the hand of the emperor's daughter, who is none other than Esclarmonde.

The very first bars of the Prologue already contain the story of the entire opera: the pipe organ plays a regular eight-bar period, with two corresponding four-bar sections separated by a weak cadence, giving it a modal and archaic nature (see Ex. 1).

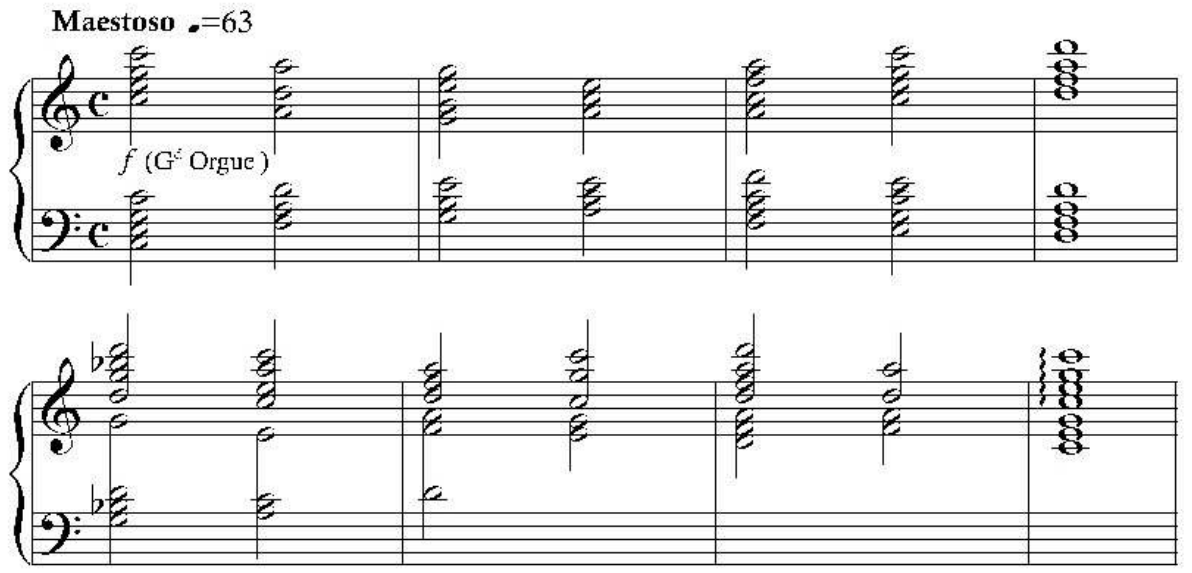

Example 1. Esclarmonde, Prologue, bars 4-11.

7 Its character is square and homophonic, representing a masculine medieval world which imperiously determines the fate of its women. This effect is underscored by the words Emperor Phorcas later sings to this music, announcing that his daughter's fate will be decided by the most demonstrative display of virile strength, a tournament. Phorcas sings, "Et la main d'Esclarmonde, et toute puissance / Appartiendront alors au vainqueur triomphant!" "'And Esclarmonde's hand, and all powers / Shall belong to the winning victor!") At the end of Act IV, the tournament is announced with the same words and the same sequence of chords.

This phrase also indicates, from the start, that the dramatic conflict is not to be a clash between magic and religion, as the orchestration of the first two occurrences of the theme might suggest. Rather, religion and magic appear as united, especially in the Prologue and in the Epilogue, in which the people congregate in the basilica of Byzantium. The conflict that erupts in this opera is between a disobedient woman and the patriarchal world to which the Church belongs. As Gérard Condé lucidly observes, the two paternal powers (the Church and Phorcas) are "equally oppressive: Esclarmonde and Roland will have to submit to their respective fathers, literal and figurative, and accept the trial of repentance or renunciation to be worthy". ${ }^{8}$ This observation is correct from the perspective of dependence on patriarchal power, but is less accurate if we consider how the two characters behave. Renunciation, repentance, 
and submission are inflicted upon Esclarmonde, whereas when Roland is deprived of his beloved, he remains active, continuing to search for her and ultimately deciding to die an honest death in a tournament - a death which eludes him because he is, and will always remain, "the victor". The near-symmetrical correspondence between the Prologue and the Epilogue, moreover, reveals Esclarmonde's failure in her attempt to be the mistress of her own destiny. The patriarch's decision will come to pass with or without the consent of the woman, who can only submit, and Esclarmonde does so in the end.

In the nineteenth century, the public, masculine sphere and the private, feminine one were separate and well defined': women had no public voice, and Esclarmonde remains voiceless to the world. In the Prologue, she does not sing at all; in the Epilogue, she sings only to herself or (in private) to her beloved. Esclarmonde's entrance, just after the proclamation by Phorcas cited above, is a silent one. ${ }^{10}$ She appears as an icon, lending herself to any interpretation. Her entrance is accompanied by arpeggios, a musical figuration which, in Massenet's work, is generally associated with the entrance of women with strong erotic potential. In this case, it is an A-flat major chord with an added sixth, played by the violins. In the operas composed after Esclarmonde - such as Thaïs or Cléopâtre - this musical characterisation of erotic femininity with arpeggios is accentuated by the use of a harp. ${ }^{11}$ In Esclarmonde, the harp is instead associated with the enchanted island and the nights of passion.

The use of leitmotifs as a compositional technique was widespread in late-nineteenthcentury French opera. It became a familiar element in French composers' musical language following the reception of Wagner's operas..$^{12}$ Like Manon, ${ }^{13}$ Esclarmonde receives two motifs, both in the Prologue. The first (Ex. 2) is generally referred to as "Esclarmonde's motif". ${ }^{14}$ Throughout the opera, this motif is associated with the physical or imagined presence of Esclarmonde. Like her name, it is assigned to Esclarmonde by her father. First, he pronounces her name while the orchestra plays the motif in C major, four-square and diatonic in the character of the opera's beginning. The motif ends on the dominant, thus seeming open-ended, even unfinished. After Esclarmonde's silent, solely physical entrance, the choir takes possession of her as an "idol," singing her motif in a homophonic texture evoking that of a hymn. In his Notice sur Esclarmonde (1890), Charles Malherbe emphasises this aspect:

This theme, pure and simple in form, traverses the entire work [...] [and] scrupulously maintains its air of slightly grave nobility and chaste elegance. It is not the ardent, passionate woman in Esclarmonde that it represents, but rather the Byzantine idol [in her]. ${ }^{15}$

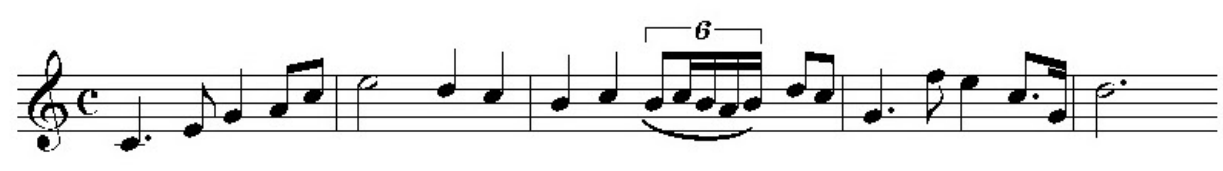

Example 2. Esclarmonde, 'Esclarmonde's motif'

Immediately after the choral interlude, the first disruptive element appears: the word amour is followed by syncopations in the violas and cellos, barely audible, and then a chromatic cantilena arises in the woodwinds and violins, accompanied by harp arpeggios. Esclarmonde's second motif (see Ex. 3a) is also related to her body, but in a 
different manner entirely: it represents her physical seductive power, a reading justified by the return of both motifs just afterwards, during her father's farewell. This motif, which I will call Esclarmonde's "seduction motif," is made up of three sections: two two-bar groups, followed by a four-bar one.
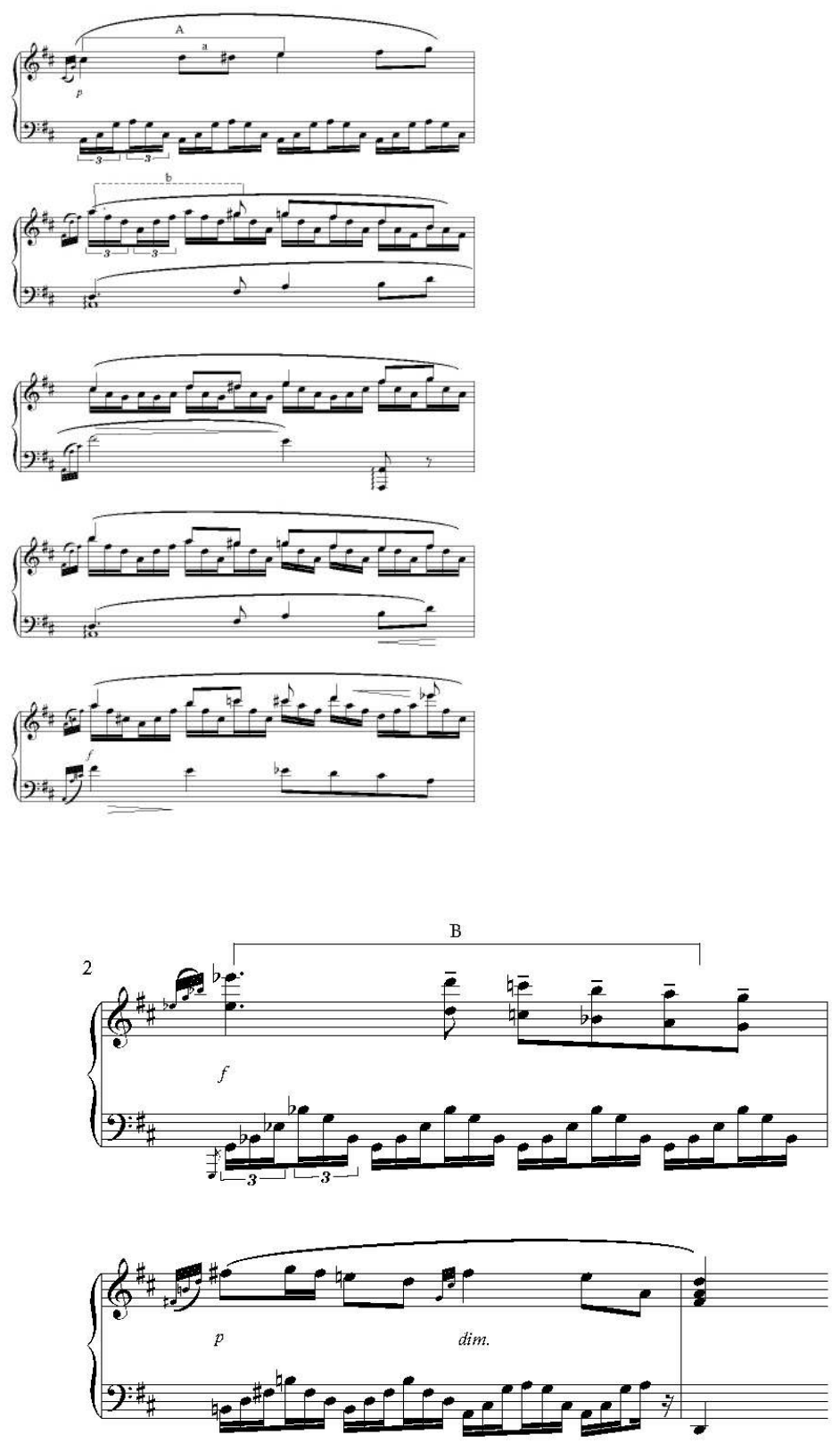

Example 3a. Esclarmonde, Prologue (piano-vocal score, p. 11) 


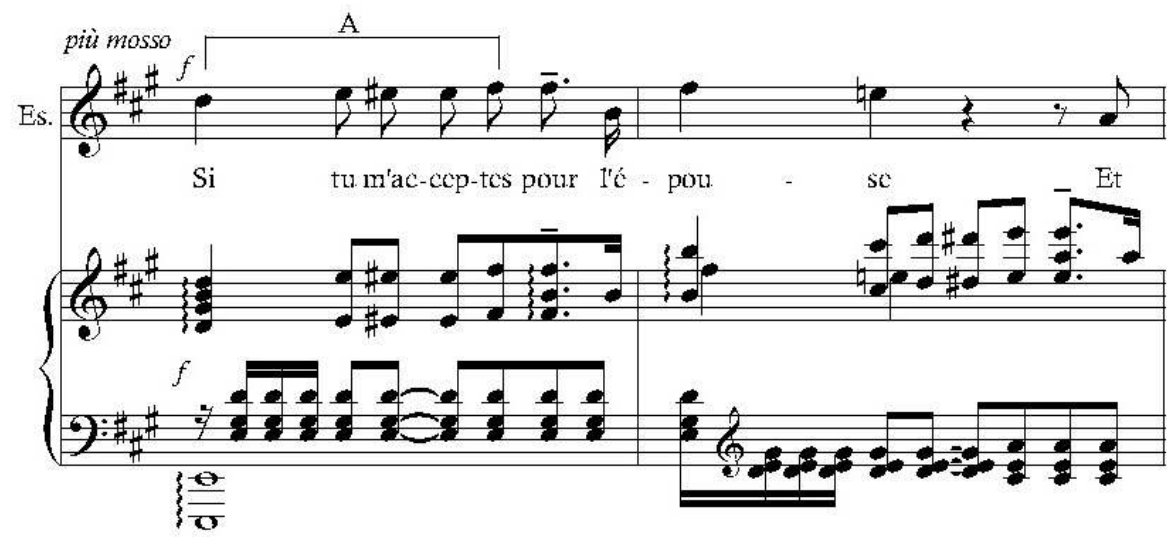

Example 3b. Esclarmonde, Act II (piano-vocal score, p. 91)

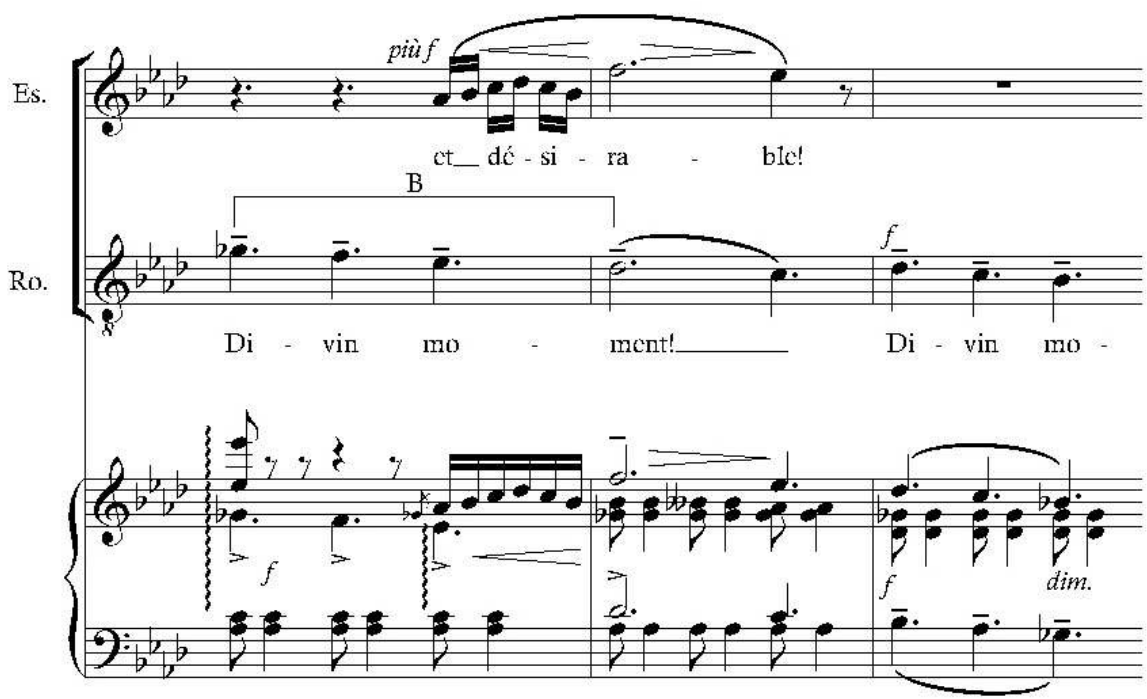

Example 3c. Esclarmonde, Act II (piano-vocal score, p. 98)

The three sections establish a gradual musical tension that builds until the release in the seventh bar and the return to the tonic in the eighth. The first section presents three elements that make up the complete motif: first, the melodic chromatic ascent (a), an element that reappears throughout Esclarmonde's musical discourse, especially in the third tableau when she offers herself to Roland (marked " $A$ " in Ex. 3b); , and second, the descending line (b) which, at its third reprise in the sixth bar, is developed in a leitmotif that Malherbe calls the "possession motif", representing what Roland describes as a "divine moment" (marked "B" in Ex. 3c). The third element consists of the harmonic movement from dominant to the tonic - opposite to that in Esclarmonde's first motif, which moves towards the dominant. The increase in tension is obtained by way of an expanded double reprise of the first two-bar group, in which 
the melodic line and the harmony are amplified. The head of Esclarmonde's first motif, played by bassoons and horns, overlaps with the start of that first reprise in the third bar, thereby creating a dissonant delay of the F-sharp that is resolved on the fifth, E, of the dominant. The melodic line ascends, in the fourth bar, to $\mathrm{B}$, rather than to the original A. The second reprise continues the chromatic line a sixth higher, achieving an even more intense effect with the syncopation in the fifth bar. The harmony moves towards the flat second degree, E-flat, evoking a Neapolitan sixth chord, before returning to the tonic, D major, via $\mathrm{B}$ minor and A major chords. In the last two bars, the forte decreases to pianissimo.

13 Condensed within these eight bars are the key components of the interlude in the middle of Act II, the sexual connotations of which are the main reason for this opera having the reputation of being an erotic work. This leitmotif appears twice in the Prologue, and the dramatic location of its appearances here indicates the basic structures for the unfolding drama. The first time (Ex, 3a), this "seduction motif" accompanies the bestowing of the insignia of power. From the start, it affirms the conflict between the "inflexible laws" that demand complete obedience - symbolised by the insignia - and Esclarmonde's individual will that points her towards union with the man she has chosen.

When Esclarmonde's two motifs return fourteen bars later, they draw attention to another determining aspect of the drama: the relationship between father and daughter. The A-flat major tonality attained here for the first time is that of the love duet in the second act. A-flat major is, moreover, a tonality strongly associated - in my view, if not for French audiences of the time - with the love duet in the second act of Tristan. Here, Phorcas joins in Esclarmonde's motif being played by the orchestra, singing the lyrics: "Ô trésor sans pareil / dont j'emporte à jamais / la radieuse image" ("Oh peerless treasure whose radiant image I shall bear forever"), words that betray an almost physical taking-possession of his daughter, to the very motif he attributed to her at the start of the Prologue: it is by his body that he is bound to her, and it is by her physical beauty that she holds power over him. By concealing her from any other man behind the veils she must wear, Phorcas carries away with him his daughter's alluring looks. This father-daughter relationship borders on incest. It is the father who, in the Epilogue, reserves the right to unveil the daughter to the victor of the tournament. In the epilogue, the "seduction motif" comes back in the same A-flat major tonality when Phorcas orders: "Voiles, tombez!" ("Veils, fall!"). If we consider the fact that veils symbolise virginity ${ }^{16}$ the erotic implications in Phorcas's relationship with his daughter are quite clear. By herself provoking her unveiling, at the hand of the Bishop of Blois, Esclarmonde commits a disobedience punishable by the penalty "pour la fille indocile et son coupable amant" ("for the disobedient daughter and her guilty lover") that is, she will lose all that her father had thus far taught and given to her.

This father-daughter relationship recalls that of Wotan and Brünnhilde. Brünnhilde, too, is punished for having committed an act of disobedience against the will of her loving father. Incestuous relationships, an element of sexuality in the decadent literature derived from Wagner's works, began to play a role for writers in the period in which Esclarmonde was created and composed. In 1884, for example, Élémir Bourges published his novel Le Crépuscule des dieux (Twilight of the Gods), and two years later, Catulle Mendès wrote Zo'har. ${ }^{17}$ The closeness of certain aspects of the Esclarmonde libretto and decadent literature elicited the following remark from critic Camille 
Bellaigue: "In the score as in the poem, too many flowers and gemstones, too much phantasmagoria and the likes; an almost constant fear of the natural and of spontaneity" ${ }^{18}$ In fact, Louis de Gramont, one of the two librettists of Esclarmonde, had a reputation for being a decadent poet, as can be seen in the accounts of the opera's premiere.

With the beginning of the second tableau (Act I), we enter the private, feminine sphere. A staging manual of the libretto, containing handwritten corrections by Massenet, states that Esclarmonde "is stretched out on a day bed [...] covered in cushions and lion skins". ${ }^{19}$ Just before the curtain rises, the audience hears Esclarmonde's motif in the first violins, which then continues with the chromatic opening to the "seduction motif". At that moment, just before Esclarmonde comes into sight, we learn that this tableau will depict the combination of the heroine's two sides. It is a dramatic moment in which, to conquer the lover she desires, Esclarmonde decides to use the power entrusted by the authority of her father. This attitude, considered too "masculine" for a young woman, annoyed bourgeois society of the day, as can be read in commentaries on Esclarmonde - "the sensual little Turk" ${ }^{20}$ - such as that by Camille Bellaigue:

Esclarmonde has not fallen in love with Roland, as Lohengrin with Elsa, out of compassion or moral attraction. Her love is physical; she desires him, unabashedly. With him, she promises herself fervent intoxication and voluptuous refinements; she will initiate this adolescent into amorous pleasures; and all of these perspectives make Esclarmonde seem to us as desirable, as she herself says, as she is desiring, but only for the senses. We do not much like women who make advances, who take all the initiative in love; or rather, we like them, first, out of courtesy, and with great pleasure, as long as they are beautiful - but our love for them is incomplete and, as it were, inferior. ${ }^{21}$

Even though the act of this amorous conquest is not feminine enough and far too active, the libretto and the music show that the heroine exists within the confines of patriarchal structures, and that everything she does is conditioned by this environment. She is in fact the embodiment of Balzac's suggestion that "Where a man lives by action, a woman lives by sentiment." ${ }^{22}$ The first word that Esclarmonde utters in the opera is the name of her beloved, and she sings it over an interval of a fourth, echoing her father who began with the same interval in the prologue. She then starts to sing her aria, showing her psychological side, whereas up to this point the audience has only seen Esclarmonde's physical side. But here, again, she reveals herself to be determined by a man.

The aria begins with a musical motif that appears several times in the opera, each time in relation to Esclarmonde's definition of herself with regard to her lover. Here, she sings: "Comme il tient ma pensée / Et règne uniquement en mon âme blessée" ("How he grips my thoughts / And reigns solely in my wounded heart") (see Ex. 4a).

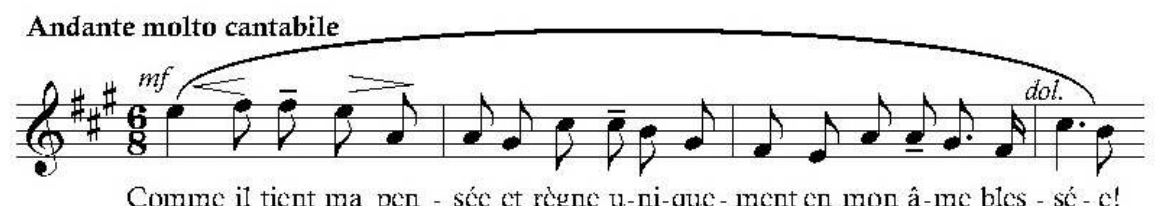

Comme il tient ma pen - sće ct règne u-ni-que-ment en mon â-me bles - sć - c! 
Then, in the following act, just after her entrance, she blesses the magic "qui bientôt vas permettre à l'heureuse Esclarmonde / De serrer dans ses bras l'objet de son amour" "'that soon will let happy Esclarmonde / Hold in her arms the object of her love" (see Ex. 4b). Shortly after that, in response to Roland's question "Qui donc es-tu?" ("But who are you?"), she defines herself in her own words, "Je suis une femme qui t'aime" ("I am a woman who loves you"; Ex. 4c).
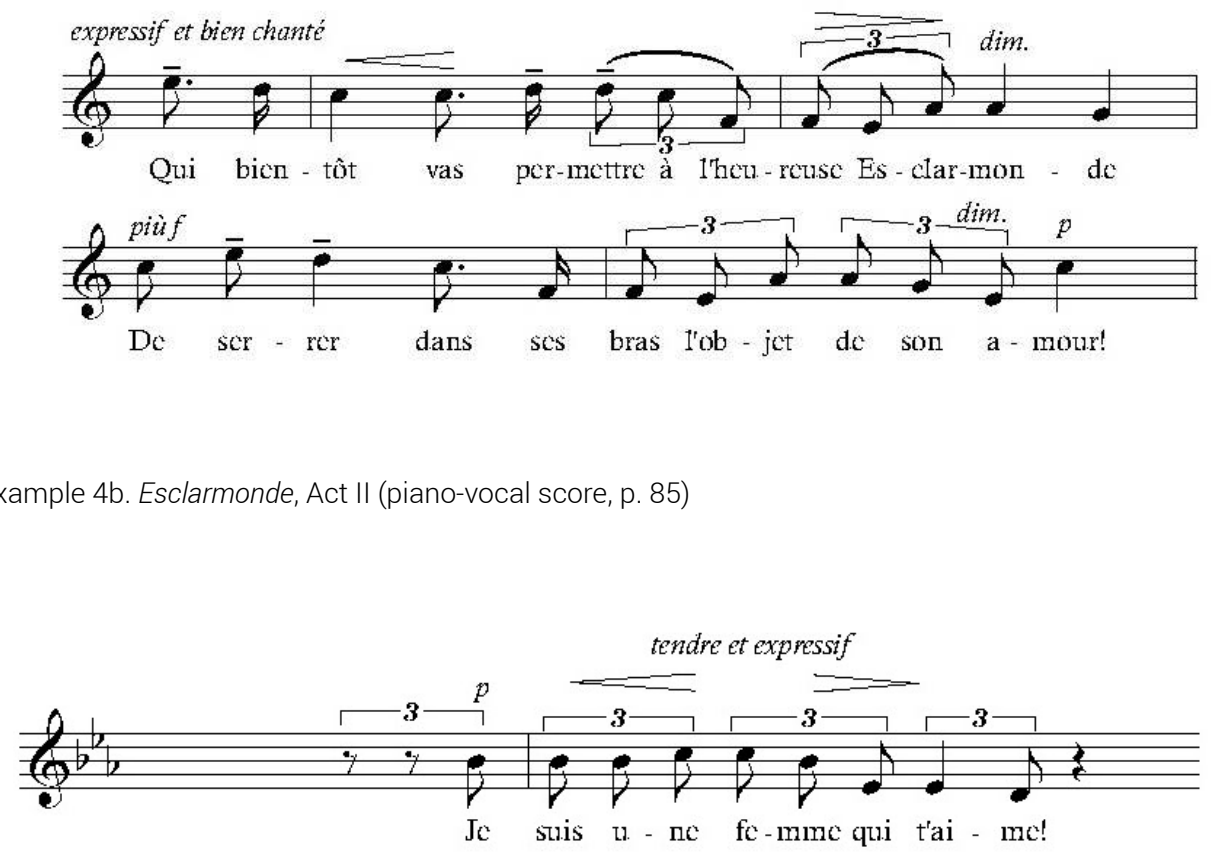

Example 4c. Esclarmonde, Acte II (piano-vocal score, p. 90)

While, on the one hand, Esclarmonde's public face is that of a symbol, to which a patriarchal authority grants relative power - on the condition that she should behave properly - she, on the other, defines herself primarily in her femininity, as the lover of a "vainqueur Glorieux" ("glorious victor") (as she describes him to her sister Parséis). In both cases, Esclarmonde's actions are reactions to a situation determined by the masculine, that is, the father and the lover. Her rebellion against the patriarchal system is fed by an exclusive fixation on the man she loves. In this respect, she corresponds exactly to the image of a woman described by Balzac: as being guided by her sentiments. Although women did appear in the public sphere in the late nineteenth century, the Pauline commandment of a silent public existence remained in effect for the official bourgeois image of women. ${ }^{23}$ The opera's resolution corresponds to the standards of these bourgeois ideals: Esclarmonde fails, and order is regained.

Her sexuality is the means Esclarmonde uses to achieve her ends. Even abusing her power only provides secondary support: "Here, we are in the midst of passionate magic and the point of view is definitely sexual." ${ }^{24}$ Esclarmonde is an unusual operatic heroine in that she openly expresses her physical desire. It was Roland's physical appearance that aroused her love - she explains in her first aria - contrary to custom which places the emphasis on "moral attraction" (Bellaigue), as can be seen in Hérodiade where Salomé begins her first aria with the words, "Il est doux, il est bon" ("He is gentle; he is 
good"). Musically, as well, Esclarmonde's sexuality is continually present - already in the orchestra after her first silent entrance in the prologue, but also in her voice from her first aria. Here, in the middle section, a melodic expansion is combined with a syncopated pulse in the accompaniment, which, given its use in the interlude in Act II, has an unambiguously sexual connotation in this opera.

The language of the libretto tests the appropriate limits for such a public spectacle as an opera: it is no longer metaphorical language - as in Carmen for example, when Carmen teases José about his lapel pin $^{25}$ - but instead is very direct. The different stages of the creation of the libretto show that this boldness gave reason for pause: how much could be said without prompting censorship, and where did the language go too far? Unfortunately, the only censorship dossier for an opera by Massenet to be missing from the collection at the Archives Nationales is that for Esclarmonde.

The first place in which the sexual impact is openly revealed in the libretto is when Esclarmonde explains to her sister how she will manage to seduce Roland, considering that she must remain veiled to keep her power.

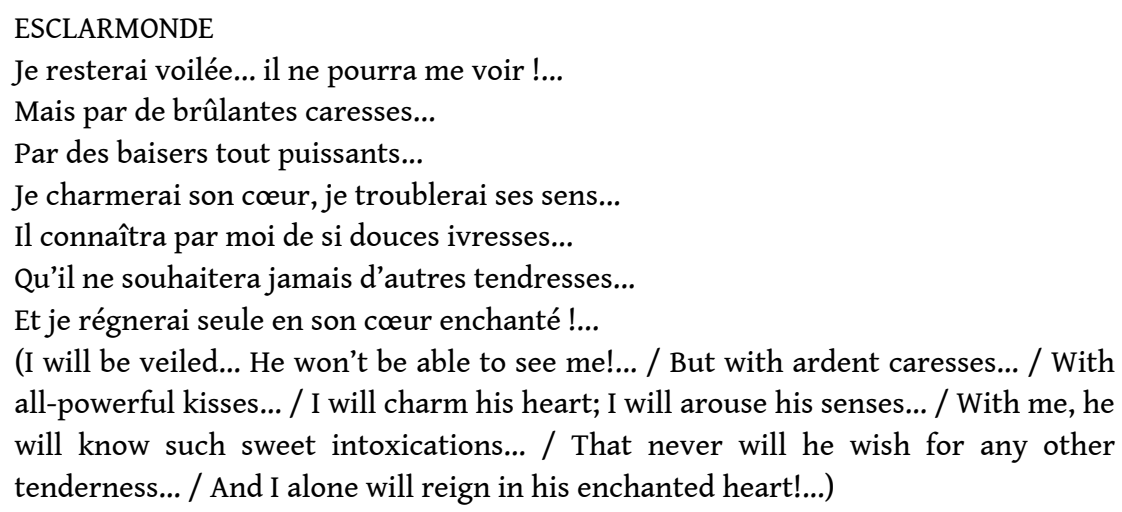

It is precisely these words that prompted Camille Bellaigue's remarks given above. But though his comments denote a rigid attitude - bearing in mind that, according to Balzac, action is masculine and that, as Bellaigue informs us, "we do not much like women who take all the initiative in love" - Esclarmonde is revealed in both the text and the music as being guided by her sentiments. The passage cited above is her reply to Parséis's question: "Mais... que devient votre pouvoir ?" ("But... What about your power?") Characterised as very traditionally feminine, Esclarmonde is clear in her desire to "alone... reign" in Roland's heart. The music here is far from the square, rhythmic, diatonic model that the prologue established to represent the masculine world, and which is then recalled by the abrupt entrance of Enéas (Parséis's lover) into the feminine world of Act I.

Comparing the manuscript of the full score and the first drafts of the piano-vocal score $^{26}$ with the published version, we see that all the text changes take place after the union of the two lovers, and that they all refer specifically to the physical aspect of their relationship. On page 111 of the published piano-vocal score, Roland vows to keep silent "Sur le secret hymen qui nous unit tous deux !..." ("About the nuptial secret that unites us two!"). An earlier version read that he would keep secret "Les divins plaisirs que tu m'a [sic] fait goûter !..." ("The divine pleasures that you have given me to taste!..."). In Act III, Roland sings of Esclarmonde, "Toi qui m'as appris la tendresse, / Par qui mon cœur fut enchanté..." ("You who taught me tenderness, / By whom my heart was enchanted..."). But in the first version, it read: "Toi qui m'as appris la tendresse, / Qui m'as appris la volupté" ("You who taught me tenderness, / Who taught me sensual 
pleasure..."). After the betrayal, Esclarmonde commands Roland: "Regarde-le, ce corps... que ta faute a perdu sans retour !..." ("Look at it, this body... that your error has irretrievably lost!"). This phrase replaces the words, "Regarde-le, ce corps... où mouraient tes désirs apaisés..." ("Look at it, this body... where your appeased desires expired..."). These corrections were not made until late in the process of composing Esclarmonde. Given that the opera's censorship dossier is lost, it is impossible to say whether these changes were self-made or done at the behest of the theatre censors. One anecdote shows that in the period of Esclarmonde, some opera goers had problems with overly evocative moments:

[Massenet] has softened and enamoured all subjects and all characters, all, including Saint John the Baptist, the fierce eater of grasshoppers, to whom he had Salomé make true declarations, so much that one day, as we were performing Hérodiade, a very Parisian mother cried out in front of us, to her daughter: "My child, do try not to listen: it is really too lustful". ${ }^{27}$

It is more difficult to capture the eroticism in the music itself, without being overly subjective or arbitrary. ${ }^{28}$ That music has a direct and intimate hold over the listener is an uncontested assertion, at least in the nineteenth century. But how can one attribute specific content to it? In vocal music, especially opera, the text can guide an interpretation. In the case of Esclarmonde, the different leitmotifs have a well-defined semiotic connotation ${ }^{29}$ - which is not always the case, for example, in such works as Puccini's operas such as La Bohème and Tosca ${ }^{30}$ - and the placement of an instrumental piece within the context of dramatic action can give it a clear meaning that it would not have had if listened to on its own. Just before the start of the famous interlude in Act II representing the sexual act itself, the two lovers are already singing to the music that will be redeployed and developed therein:

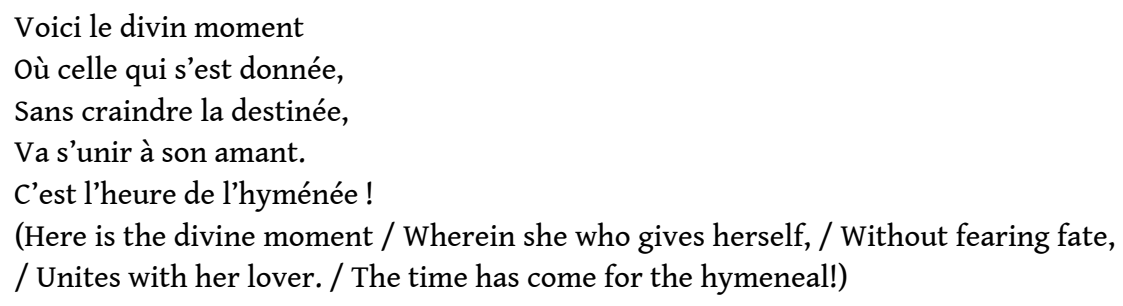

Esclarmonde then leads Roland to some manner of bed at the back of the stage, and a curtain of roses comes down from the ceiling - a scenic detail on which Massenet insisted in the staging manual, surely aware that the rose, as a literary symbol, has a sexual connotation. ${ }^{31}$

Unlike literature, music does not allow the listener any escape; you can close your eyes, but you cannot close your ears. In a text, the author can create distance from an erotic, even sexual, incident. In Madame Bovary, for example, the detailed description of Emma and Rodolphe's horseback ride foreshadows their sexual union, which occurs just afterwards and is merely hinted at in a few words. In this case, any overly direct description is avoided. ${ }^{32}$ However, there is not the same distance in music, and the interlude in Act II of Esclarmonde offers one of the most striking examples of this. Richard O'Monroy's cynical account describes the effects that the music had on the audience:

Thanks to M. Massenet's music, every detail of these adorable moments is recounted to us. It begins softly like a gentle caress, and then the movement continues to build to a frenzy of brass instruments and the final crash of the symbols expressing the cry of triumphant and satisfied passion. All in the audience 
are superaroused to the point of climax. Oh! This melody! This melody! Men wink with delight; women blush behind their fans. "Encore" they cry out with erotic frenzy. To think that young girls will be brought on pre-marital assignations and will hear this hymn to sensual love. The orchestra recommences. And Roland? ... Blimey, will he be worn out! $!^{33}$

In the reviews of the opera after its premiere ${ }^{34}$ one notices everywhere an attempt to contain the overly direct impact of the music by trying to find a verbal equivalent. It is a way of taking distance from the excessively suggestive music, and yet, at the same time, the music provides a pretext approved by the official culture, giving critics, for once, permission to unleash themselves in rather risqué prose. In L'Écho de Paris, Henry Sauer wrote:

The interlude that links the two tableaux in Act II is a Sapphic ode in which we feel the throbbing of the unnerving and passionate embrace - all the violence, confusion and lethargy of carnal love. The phrase burns with fervour and escapes the oppressed bosom in sobs, enveloped in an orchestration full of warm caresses and sweet embraces. ${ }^{35}$

Perhaps the most striking example is Camille Bellaigue's critique for the Revue des Deux Mondes:

The progression that ends the duet is not particularly novel, either; a gripping crescendo climbs note by note, until a predictable explosion brings down the curtain. This was the time to veil behind the roses the almost-frenzied passions of Esclarmonde and her beloved. This was where it would be natural to convey in a few bars the climax and the calm that follows, as Gounod did in Faust at the end of the garden act. But M. Massenet has gone much further. Thanks to an astonishingly expressive orchestral peroration, which is quite powerful - thanks to this entr'acte (which is one for the audience alone) - we hear what we do not see. We are witnesses with our ears to what we cannot observe with our eyes. Never before, it seems to me, has anyone described in sound so accurately, and in such detail, the physical manifestation of human tenderness (you can see that I am choosing my words delicately). Every detail is noted and assigned an intensity; the violins begin softly; then the violas sweep in, and the entire strings; the sounds swell, the movement quickens, all culminating in a full and frightfully unequivocal final burst. Go, listen to this eminently suggestive symphony, and, in the words of La Fontaine's pigeon - the bird to quote in such an instance - "You'll think it all occurred to you". The orchestra, in its sound, defies virtue. Massenet's instrumentation was already lush; here it is luscious, and the blossom of sensuality that the young master had always cultivated has finally bloomed like the aloe flower, with a thunderous crash. This is not to say it is much ado about nothing; this nothing is something, something heavenly, even; but the subject treated in this way gives us a vision, or hearing, rather, of love that is too exclusively sensual. The unison of these enraptured violins represents too much the unison of two bodies (I do not mean the instruments'), and too little that of two souls. It is, I believe, lacking in aesthetic subtlety, a displacement and, perhaps, debasement of the ideal of the musician. [...] The nuptial noise gradually subsides; the tension gives way to calm; but then the curtain rises again on a second tableau of love - love that is satisfied and spent, something like the old engraving "The Empty Quiver". A new, naturally calmer, scene begins between the lovers. ${ }^{36}$

31 In a response to this article, appearing in Le Monde Artiste, Maurice Lefèvre points out the manner in which the pretence of indignation about "the realism of this music" (Bellaigue) becomes an excuse to describe in great detail precisely what is deemed inappropriate.

Naturally calmer is so apt. I like this naturally more than I can say. Naturally delights me, even as it reassures me: things can so easily go so wrong. But, not to worry, the 
scene is naturally calmer. What I would not give to have found this naturally myself. How good it is, as M. Jourdain said, how beautiful it is to be learned. For, naturally is a delightful philosophy. I can almost hear the sorely missed M. Caro teaching his bevy of pretty and assiduous listeners, and telling them with the slight smile that so easily won all their hearts and enveloping his reflections in a slow, calming gesture: - The scene that follows, mesdames, is naturally calmer.

I can see the blushing cheeks of the shy ones, impish eyes bright with mischief, and I hear the lips of an ingénue murmuring dreamily:

- Why naturally?

A lovely adverb, and how it says so well what it means to say! ${ }^{37}$

The main reason this interlude elicited so much commentary is because of its position in the opera: in the middle of an act, between two scenes that do not require a set change. Audiences hear this piece in the dark, in front of a lowered curtain. They are left to their own imagination, guided by the verses of the love duet and the dramatic situation. What was wholly unheard-of in this interlude were not just the musical devices Massenet used, but also the fact that the erotic music was not in its usual place in an opera, for instance in a seductive aria or, most typically, the ballet. At least since Robert le Diable, ballet represented the fantastic and sensual in French opera. But by ritualising - essentially institutionalising - the release of the Dionysian, the erotic impact loses all immediacy. The famous Venusberg "Bacchanale" is first and foremost an oddly placed ballet, added for the first Parisian performance of Tannhäuser in 1861. Even before composing the music, Wagner developed a ballet plot, in which he combined motivic sketches with a choreographic description. The plot begins as follows:

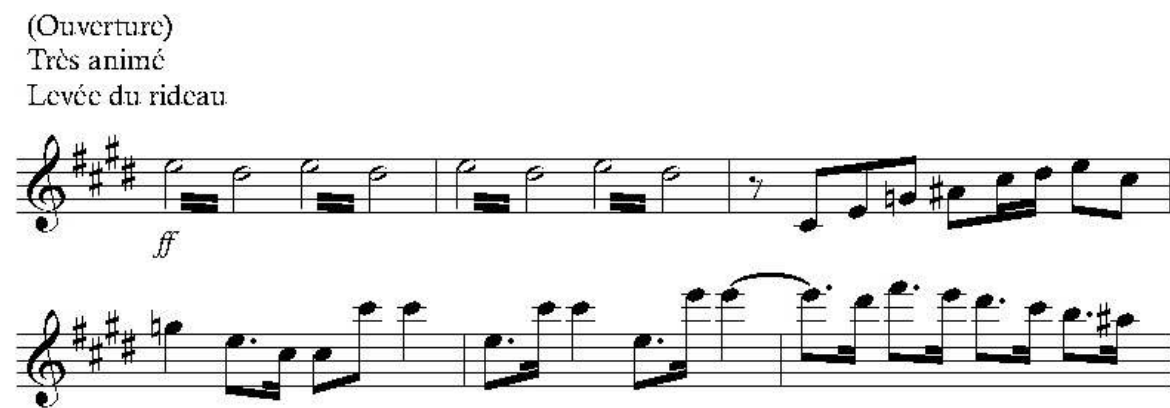


Danse voluptueuse, lascive. Les nymphes excitent les jeunes hommes de se mêler avec eux [sic]; ceux-ci descendent des praticables, partout-

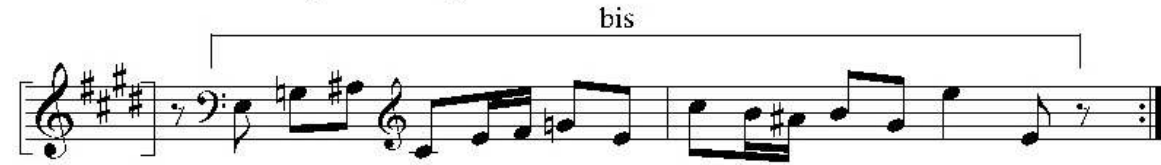

bis

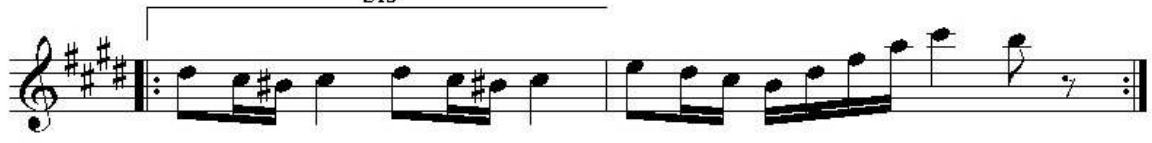

(danse commence - Cancan mythologique.)

Example $5 b^{38}$

Through the choreography and staging, the audience's imagination is captured and channelled within the part of an opera, the ballet, that could often be a shallow form of entertainment. The two versions of Thaïs show how, ultimately, the institution has the last word: in the first version (1894), Act II contained an interlude comparable to the one in Esclarmonde, called the Symphonie des amours d'Aphrodite. It was placed at the moment when Thaïs is about to act out the passions of Aphrodite, a scene already anticipated in Act I during Athanaël's "Vision". The curtain comes down and the audience is confronted with a piece of music that is similar in its musical structure with unrelenting rhythmic movement, a great climax and release - to the Act II interlude of Esclarmonde. For the revival of Thaïs in 1898, Massenet removed this piece and added to the end of Act II a grand ballet in seven numbers that represented a perfectly traditional Dionysian celebration in front of Thaïs's house. ${ }^{39}$

If we compare the three operas mentioned at the start of this essay - Hérodiade, Esclarmonde and Thaïs - we can find several points in common with regard to the erotic: a distant historical era, exoticism, a woman's influence through the use of the erotic, and the combination of religion and eroticism. The far-off eras in which the three operas take place and the exotic ambience create distance from nineteenth-century Parisian audiences. Werther, Manon and Sapho, set closer to Massenet's own time and place, do not contain comparable erotic moments. It is the double distancing that chiefly permits so direct an approach to eroticism in these three works. But the erotic impact, especially of Esclarmonde and Thaï, reflects the librettists' male fantasy projected onto the Other, represented by exotic women..$^{40}$ By comparing these operas to Samson et Dalila by Camille Saint-Saëns, for example, one detects in them an attitude towards eroticism no longer justified by heroic or even patriotic action, such as Dalila's when she uses her powers of seduction to achieve her ends. Dalila's sexuality is a means - albeit dangerous and effective - to serve as a weapon; Esclarmonde's and Thaïs's sexuality is an end unto itself.

Looking at how the librettos unfold, it is immediately clear that despite the temporary power women gain through their sexuality, they ultimately end up back in their place as hereditarily defined by bourgeois society: married and obedient, like Esclarmonde; or simply dead, like Thaïs and Salomé. ${ }^{41}$ At first glance, Massenet's music seems to support this vision of women, given that, in the traditional manner, musical order is 
restored with the final chord. While Thaïs dies serenely to a D major chord, Esclarmonde's "joy" is celebrated with a robust chorus in E-flat major. But Massenet's scores reveal a much more sophisticated form of musical characterisation.

In Esclarmonde, the two male lovers, Enéas and Roland, develop their musical eloquence only under the guidance of women. Enéas's first entrance brings a comic touch to the opera. He recounts his chivalrous exploits to the two women, but with a melodic and prosodic clumsiness that is especially flagrant coming just after the duet between Esclarmonde and her sister which featured expansive melodic lines, with Parséis then asking her fiancé for news with a perfect mastery of prosody.
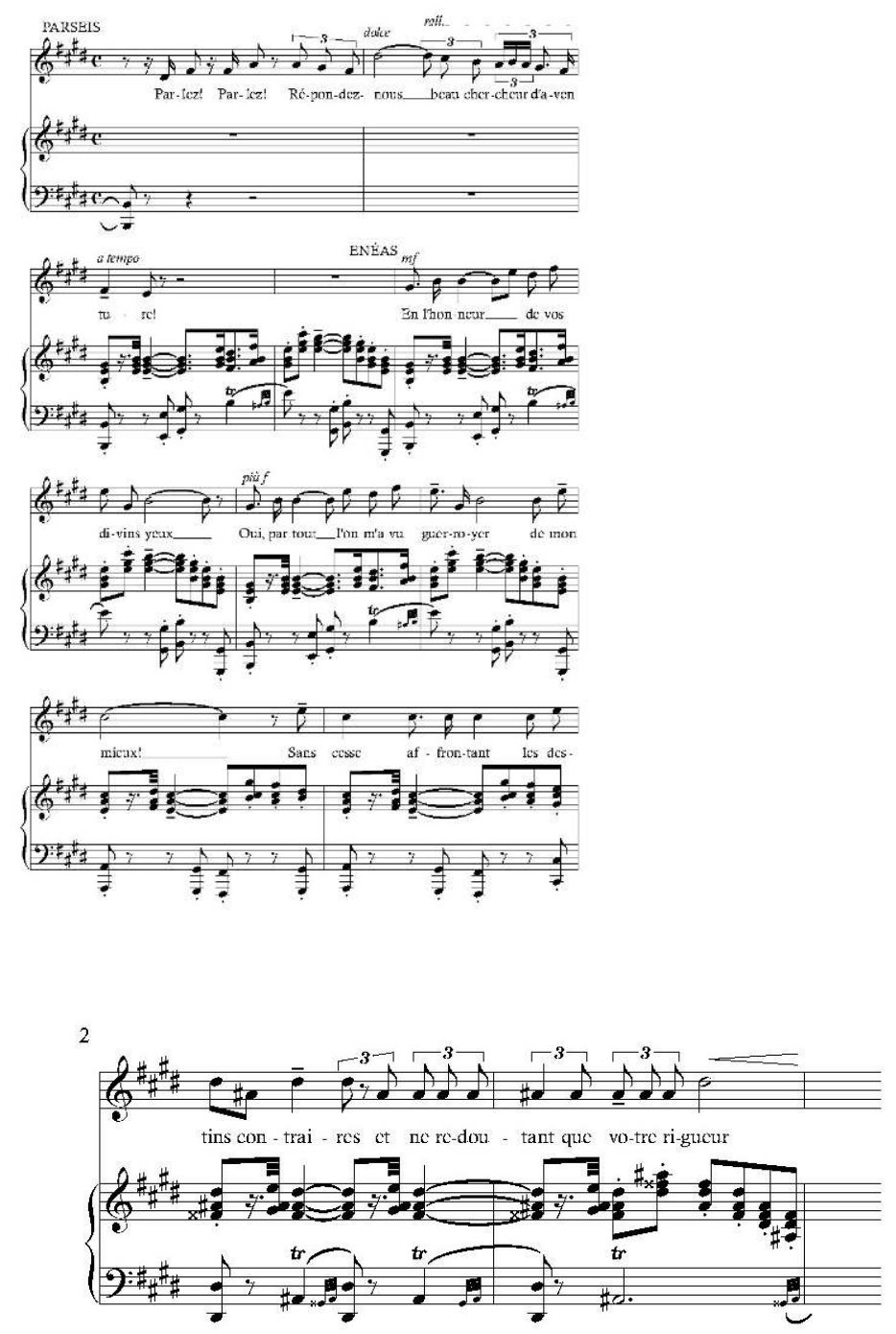

Example 6. Esclarmonde, Act I (piano-vocal score, pp. 38-40).

Only in his love duet with Parséis does Enéas manage to sing properly and lyrically, echoing the cantilena delivered by his fiancée ("Oui, je permets l'espoir"; "Yes, I grant hope"). This musical relationship is repeated between Esclarmonde and Roland, if without the comic element. Like Enéas, Roland mainly expresses himself in recitative, only finding his way into lyric expression when echoing his lover during the love duet. Only after their union does Roland become capable of singing a melodic line developed by himself ("Chère épouse, ô chère maîtresse"; "Dear wife, o dear mistress"). Esclarmonde 
proves to be the character with the richest range of musical expression in the opera. The register of her vocal delivery includes vertiginous coloraturas (ex. 7a) and lyric prose (ex. 7B) - both belonging to her alone.

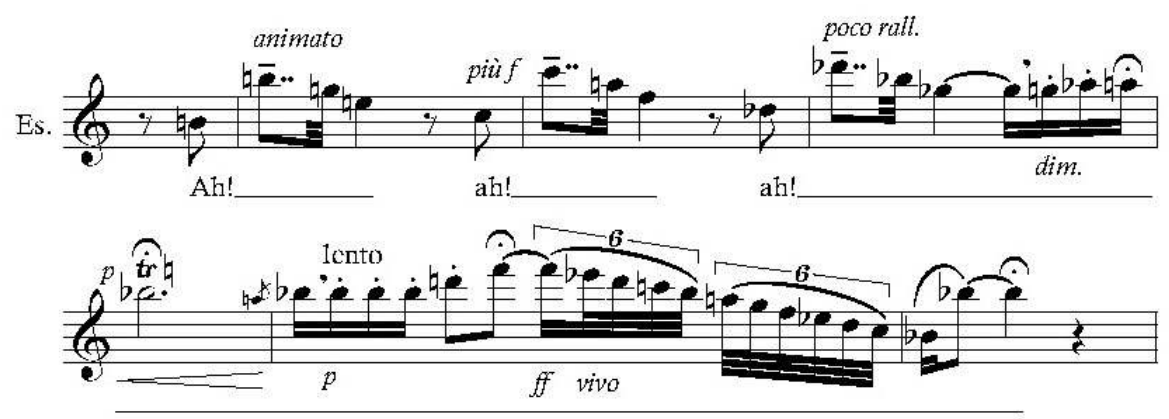

Example 7a. Esclarmonde, Act III (piano-vocal score, p. 209).
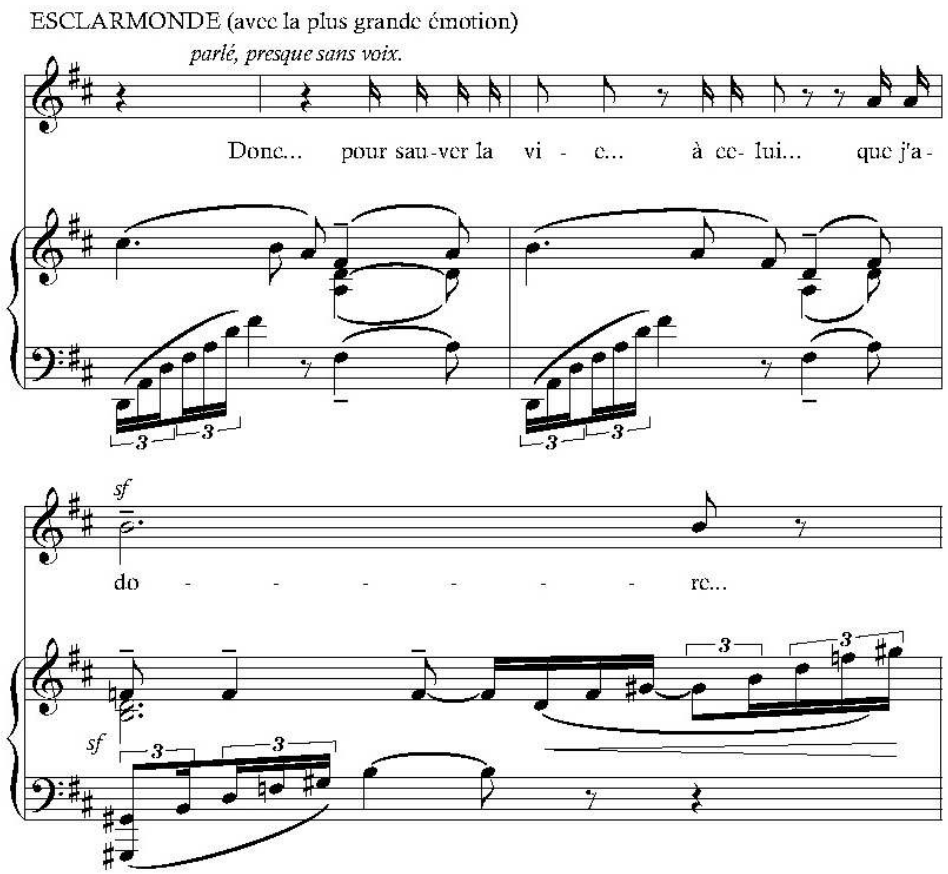

Example 7b. Esclarmonde, Acte IV (piano-vocal score, p. 265).

In all three operas - Hérodiade, Esclarmonde and Thaï - Massenet gives the women more developed musical capacity than the men. This is likely what prompted Debussy's remark that Massenet would seek "in music the materials to document the story of the female soul", ${ }^{42}$ a fairly widespread idea at the time.

39 A final aspect that these three "erotic" operas have in common is the combination of religion and eroticism. Even though this relationship is different in each case, religious authority is generally denounced as harsh, brutal and intolerant. Athanaël means not only to tear Thaïs away from her own life in an authoritarian show of force, but also demands the destruction - symbolised in the small statuette of Eros - of everything 
representing refinement, beauty and love. And in Esclarmonde, the bishop shatters the lovers' joy through his violent entrance into Roland's bedroom. Musically, the intervention of ecclesiastical power is generally translated into a square and simple language (modal or diatonic), as opposed to the triple-time, syncopated, chromatically inclined erotic world, as for example in Act III of Esclarmonde: the two lovers reunite to a musical section from the Act II interlude. Just at the point when the resolution in the E major tonic should happen, a C major chord abruptly cuts off the musical development.

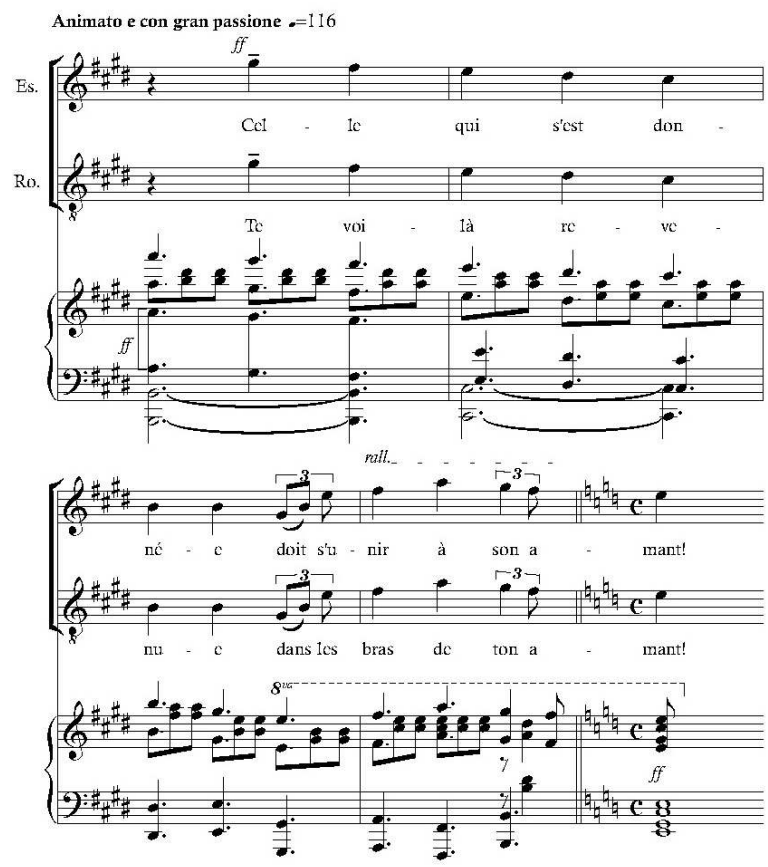

Example 8. Esclarmonde, Acte III (piano-vocal score, p. 213).

Contrary to his later reputation, Massenet did not lend himself to saccharine religious images. While there is religious power at play in his operas, it mainly appears as an antagonist. The anecdote reported by Louis Schneider, according to whom Massenet requested of Paul Milliet "a little love poem in which all the mystery of the Christian religion is applied to sensual passion", was only noted down at the end of Massenet's life, and is contradicted by the documented facts about the genesis of Hérodiade. ${ }^{43}$

The erotic plays two important roles in Massenet's works: it is uniquely shaped in each composition, but it also has a commonality insofar as the erotic is revealed as a woman's innate means of gaining influence. Whatever the outcome (generally a disaster for the heroine), the erotic is a disruptive factor, an instrument of disobedience against a masculine structure, a powerful weapon and the expression of her personality. Musically, the erotic opens up the possibility of developing all facets of the musical language of the time, whereas the masculine or religious frameworks were much more limited in terms of musical devices. 


\section{BIBLIOGRAPHY}

ABBATE Carolyn, The «Parisian Tannhauser », thèse de doctorat, Princeton, 1984.

BART Benjamin F., « The Spirit of the Erotic Wit in French Literature », HARDEE A. Maynor (dir.), Eroticism in French Literature (French Literature Series, X), Columbia, University of South Carolina Press, 1983, p. 88-101.

BAUER Henry, «Les premières représentations ", L'Écho de Paris, $6^{\mathrm{e}}$ année, 17 mai 1889, p. 2-3.

BelLaigue Camille, « M. Jules Massenet », L'Année musicale 1888-1889, Paris, 1890, p. 69-81.

BELLAIGUE Camille, « Revue musicale » (Esclarmonde), La Revue des Deux Mondes, livraison du $1^{\mathrm{er}}$ juin 1889 , p. 698-704.

CLÉMENT Catherine, L'Opéra ou la défaite des femmes, Paris, Grasset, 1979.

CONDÉ Gérard, «Commentaire littéraire et musical [d'Esclarmonde] », L'Avant-Scène Opéra, ${ }^{\circ}$ 148, septembre-octobre 1992, p. 36-67, p. 38.

DEBUSSY Claude, Monsieur Croche et autres écrits, éd. par François LESURE, Paris, Gallimard, 1987, p. 59.

DÖHRING Sieghart, « Musikalischer Realismus in Puccinis Tosca », Analecta Musicologica, 22, 1985, p. 249-296.

DÖHRING Sieghart, « Wagnerismus in Frankreich. Zum Einflu.S des Musikdramas auf die französische Oper », Neue Züricher Zeitung, Femausgabe Nr. 62, 16 mars 1990, p. 43.

FAUSER Annegret (dir.), Jules Massenet, 'Esclarmonde’ : Dossier de presse parisienne (1889), Weinsberg, L. Galland, 2001.

FAUSER Annegret, « “C'est vraiment trop voluptueux !” Zur Entstehung und musikalischen Dramaturgie von Massenet's Hérodiade », Jules Massenet: Hérodiade, Programmheft der Wiener Staatsoper, Wien, 1995, p. 11-22.

FAUSER Annegret, « Esclarmonde, un opéra wagnérien? ", L'Avant-Scène Opéra, n 148 , septembreoctobre 1992, p. 68-73.

FURMAN Nelly, « Languages of love in Carmen », GROOS Arthur et PARKER Roger (dir.), Reading Opera, Princeton, Princeton University Press, 1988, p. 168-183.

GILLIS Patrick, «Thaïs dans tous ses états. Genèse et remaniements », L'Avant-Scène Opéra, $\mathrm{n}^{\circ} 109$, mai 1988, p.66-74.

HUEBNER Steven, « Carmen de Georges Bizet : une corrida de toros », PRÉVOST Paul (dir.), Le Théâtre lyrique en France au XIX ${ }^{e}$ siècle, Metz, Éditions Serpenoise, 1995, p. 181-218.

HUEBNER Steven, Les Opéras de Charles Gounod, Arles, Actes Sud, 1994.

KABBANI Rana, Europe's Myth of Orient, London, Pandora, 1986.

KAHANE Martine et WILD Nicole (dir.), Wagner et la France, Paris, Herscher, 1983, p. 158-173.

KERBER Linda K., « Separate Spheres, Female Worlds, Woman's Place: The Rhetoric of Woman's History », The Journal of American History, 75, 1988-1989, p. 9-39.

KERST Léon, « Premières représentations », Le Petit Journal, 27e année, 17 mai 1889, p. 3. 
KOPPEN Erwin, Dekadenter Wagnerismus. Studien zur europäischen Literatur des Fin de siècle, Berlin, New York, de Gruyter, 1973.

LAROUSSE Pierre (dir.), Grand Dictionnaire universel du XIX siècle : français, historique, géographique, mythologique, bibliographique..., 17 vol., Paris, Administration du Grand dictionnaire universel, 1866-1890.

LEFÈVRE Maurice, « À propos d'Esclarmonde », Le Monde Artiste, $29^{e}$ année, 23 juin 1889, p. 383-386.

LOCKE Ralph P., « Constructing the Oriental “Other”: Saint-Saëns's Samson et Dalila », Cambridge Opera Journal, 3, 1991, p. 261-302.

MALHERBE Charles, Notice sur Esclarmonde, Paris, Fischbacher, 1890.

MARTIN-FUGIER Anne, La Bourgeoise. Femme au temps de Paul Bourget, Paris, Grasset, 1983.

MCCLARY Susan, Feminine Endings. Music, Gender and Sexuality, Minneapolis, University of Minnesota Press, 1991.

MCCLARY Susan, Georges Bizet: Carmen (Cambridge Opera Guide), Cambridge, Cambridge University Press, 1992.

NECTOUX Jean-Michel, « Musique, Symbolisme et Art nouveau. Notes pour une esthétique de la musique française fin de siècle », STENZL Jürg (éd.), Art nouveau, Jugendstil und Musik, Zürich, Atlantis, 1980, p. 13-30.

o'MONRoy Richard [pseud. du vicomte de Saint-Geniès], « La Soirée Parisienne », Gil Blas, 17 mars 1889 , p. 3.

PELADAN Joséphin, « Critique musicale », La Grande Revue Paris et Saint-Pétersbourg, $2^{\mathrm{e}}$ année, 25 mai 1889, p. 408-410.

SAID Edward W., Orientalism. Western Conceptions of the Orient, London, Penguin, 1991.

SCHNEBEL Dieter, «Zweiter Akt - musikalisches Triebleben (Ein Hörprotokoll) », Denkbare Musik: Schriften 1952-1972, éd. par Hans Rudolf zELLER, Köln, M. DuMont Schauberg, 1972, p. 85-90.

SOLENIÈRE Eugène de, Massenet. Étude critique et documentaire, Paris, Bibliothèque d'art de La Critique, 1897.

SoLIE Ruth (dir.), Musicology and Difference. Gender and Sexuality in Music Scholarship, Berkeley etc., University of California Press, 1993.

SoLIE Ruth, «Changing the Subject », Current Musicology, 53, 1993, p. 55-65.

\section{NOTES}

1. SOLENIÈRE Eugène de, Massenet. Étude critique et documentaire, Paris, Bibliothèque d'art de La Critique, 1897, p. XXIII.

2. SOLENIÈRE, Massenet, p. X.

3. SOLENIÈRE, Massenet, p. XVII.

4. See FURMAN Nelly, "Languages of love in Carmen", GROOs Arthur and PARKER Roger (eds.), Reading Opera, Princeton, Princeton University Press, 1988, p. 176 et seq.; MCCLARY Susan, Feminine Endings. Music, Gender and Sexuality, Minneapolis, University of Minnesota Press, 1991; McClary Susan, Georges Bizet: Carmen (Cambridge Opera Guide), Cambridge, Cambridge University Press, 1992; HUEBNER Steven, "Carmen de Georges Bizet : une corrida de toros," PRÉVOST Paul (ed.), Le Théâtre 
lyrique en France au XIX eiècle, Metz, Éditions Serpenoise, 1995, p. 181-218. In Thais, this traditional side was even reinforced in the second version from 1898, notably with the cutting of the interlude after the second tableau, called the Symphonie des amours d'Aphrodite.

5. On the subject of eroticism in Act II of Tristan und Isolde, see SCHNEBEL Dieter, "Zweiter Akt musikalisches Triebleben (Ein Hörprotokoll)," Denkbare Musik: Schriften 1952-1972, ed. by Hans Rudolf ZELLER, Köln, M. DuMont Schauberg, 1972, p. 85-90. Wagner's works performed in Paris are listed in KAHANE Martine and WILD Nicole (eds.), Wagner et la France, Paris, Herscher, 1983, p. 158-173.

6. KERST Léon, « Premières représentations », Le Petit Journal, Year 27, 17 May 1889, p. 3.

7. The father-daughter-lover constellation of characters is a constant in bourgeois drama (bürgerliches Trauerspiel) from the eighteenth century onward.

8. CONDÉ Gérard, "Commentaire littéraire et musical [d'Esclarmonde], " L'Avant-Scène Opéra, no. 148, September-October 1992, p. 36-67, p. 38.

9. See KERBER Linda K., "Separate Spheres, Female Worlds, Woman's Place: The Rhetoric of Woman's History," The Journal of American History, 75, 1988-1989, p. 9-39, especially p. 13-14.

10. In his study of Gounod's operas, Steven Huebner cites Marguerite's entrance in Faust as paving the way for the silent entrances in the works of Massenet (Esclarmonde) and Puccini (Turandot). See HUEBNER Steven, Les Opéras de Charles Gounod, Arles, Actes Sud, 1994, p. 141.

11. I thank Katherine Ellis for reminding me that in the dialogue between Brünhilde and Siegmund, in Wagner's Die Walküre, the harps erupt at the mention of the female body.

12. See DöHRING Sieghart, "Wagnerismus in Frankreich. Zum Einflu.S des Musikdramas auf die französische Oper," Neue Züricher Zeitung, Femausgabe Nr. 62, 16 March 1990, p. 43; FAUSER Annegret, «Esclarmonde, un opéra wagnérien ? " L'Avant-Scène Opéra, no. 148, September-October 1992, p. 68-73.

13. In an interview for the first performance of Manon, Massenet explained, "One character, one motif; Manon alone, whose type is a mix of melancholy and mirth, has two, to clearly indicate this alternation" (Le Figaro, 19 January 1884, p. 1).

14. MALHERBE Charles, Notice sur Esclarmonde, Paris, Fischbacher, 1890.

15. MALHERBE, Notice sur Esclarmonde, p. 59.

16. See in the nineteenth-century French dictionary Larousse du XIX siècle: "The veil was adopted by women among the early Christians. Their heads were veiled not only when they went out, but also to pray and to prophesy. However, the veil worn as the virginal flammeum was the badge of virgins. Bishops consecrated virgins by imposing the veil." LAROUSSE Pierre (ed.), Grand Dictionnaire universel $d u X_{X} X^{e}$ siècle: français, historique, géographique, mythologique, bibliographique..., 17 vol., Paris, Administration du Grand dictionnaire universel, 1866-1890.

17. See KOPPEN Erwin, Dekadenter Wagnerismus. Studien zur europäischen Literatur des Fin de siècle, Berlin, New York, de Gruyter, 1973, p. 134-164.

18. Bellaigue Camille, «Revue musicale » (Esclarmonde), La Revue des Deux Mondes, June 1st, 1889 Issue, p. 698-704, p. 700.

19. F-Pn Vma.ms .497, ff. $9 \mathrm{v}^{\circ}$ and $10 \mathrm{r}^{\circ}$.

20. Bellaigue, « Revue musicale " (Esclarmonde), p. 699. In characterising the heroine as oriental in his critique of Esclarmonde, Bellaigue follows the late nineteenth-century trend of orientalising women who are actively erotic. LOCKE Ralph P., “Constructing the Oriental 'Other': Saint-Saëns's Samson et Dalila", Cambridge Opera Journal, 3, 1991, p. 261-302.

21. BELLAIGUE, « Revue musicale » (Esclarmonde), p. 699-700.

22. "La femme vit par le sentiment, là où l'homme vit par l'action". This sentence is quoted in the Petit Robert (Dictionnaire alphabétique de la langue française, by Paul Robert, Paris, 1989, p. 22). Given that the choice of example phrases is a deliberate act by a major dictionary, it is important to note that even in a recent edition ("reviewed, corrected and updated" [!]), an example employing the 
old cliché of "feminine sentiment" versus "masculine action" is still used to illustrate to readers (including female readers[!]) the meaning of the word action.

23. On the notion of bourgeois women in the late nineteenth century, see: MARTIN-FUGIER Anne, $L a$ Bourgeoise. Femme au temps de Paul Bourget, Paris, Grasset, 1983.

24. PELADAN Joséphin, "Critique musicale », La Grande Revue Paris et Saint-Pétersbourg, Year 2, 25 May 1889, p. 408.

25. HUEBNER, « Carmen de Georges Bizet », p. 188.

26. I wish to thank Patrick Gillis who provided me with the following information.

27. Bellaigue Camille, «M. Jules Massenet », L’Année musicale 1888-1889, Paris, 1890, p. 69-81, p. 70.

28. Along with Susan McClary's book (Feminine Endings), other recent publications discuss this issue, including several articles in the following volume: solie, Ruth (ed.), Musicology and Difference. Gender and Sexuality in Music Scholarship, Berkeley etc., University of California Press, 1993.

29. On this subject, see FAUSER, «Esclarmonde, un opéra wagnérien?».

30. See DöHRING Sieghart, "Musikalischer Realismus in Puccinis Tosca", Analecta Mustcologica, 22, 1985, p. 253-256.

31. See NECTOUX Jean-Michel, « Musique, Symbolisme et Art nouveau. Notes pour une esthétique de la musique française fin de siècle », STENZL Jürg (ed.), Art nouveau, Jugendstil und Musik, Zürich, Atlantis, 1980, p. 26-30.

32. BART Benjamin F., "The Spirit of the Erotic Wit in French Literature", HARDEE, A. Maynor (ed.), Eroticism in French Literature (French Literature Series, X), Columbia, University of South Carolina Press, 1983, p. 91-93.

33. o'MONROY Richard [pseud. of the Count of Saint-Geniès], «La Soirée Parisienne », Gil Blas, 17 March 1889, p. 3.

34. On critics of the premiere of Esclarmonde, see FAUSER Annegret (ed.), Jules Massenet, Esclarmonde : Dossier de presse parisienne (1889), Weinsberg, L. Galland, 2001.

35. BAUER Henry, « Les premières représentations », L'Écho de Paris, Year 6, 17 May 1889, p. 2-3.

36. BELLAIGUE, « Revue musicale » (Esclarmonde), p. 703-705.

37. LEFÈVRE Maurice, «À propos d'Esclarmonde », Le Monde Artiste, Year 29, 23 June 1889, p. 385-386. 38. Cité d'après ABBATE Carolyn, The "Parisian Tannhauser ", thèse de doctorat, Princeton, 1984, p. 278.

39. GILLIS Patrick, "Thaïs dans tous ses états. Genèse et remaniements ", L'Avant-Scène Opéra, no. 109, May 1988, p. 66-74.

40. In his aforementioned article, Ralph $P$. Locke sums up the issue of Orientalism in the nineteenth century and its importance for French opera. An analysis of the notion of the "other" can be found in Said, Edward W., Orientalism. Western Conceptions of the Orient, London, Penguin, 1991; see also KABBANI, Rana, Europe's Myth of Orient, London, Pandora, 1986.

41. This narrative model is set within the conception of female biographies, as Ruth Solie discusses in her article "Changing the Subject", Current Musicology, 53, 1993, p. 55-65, especially p. 56. See also CLÉMENT Catherine, L'Opéra ou la défaite des femmes, Paris, Grasset, 1979.

42. DEBUSSY Claude, Monsieur Croche et autres écrits, ed. by François LESURE, Paris, Gallimard, 1987, p. 59.

43. On Hérodiade, see FAUSER Annegret, “'C'est vraiment trop voluptueux!' Zur Entstehung und musikalischen Dramaturgie von Massenet's Hérodiade”, Jules Massenet: Hérodiade, Programmheft der Wiener Staatsoper, Vienna, 1995, p. 11-22. 


\section{ABSTRACTS}

Massenet's opera Esclarmonde, premiered in Paris during the 1889 Exposition Universelle, offers a particularly powerful case study for the ways in which a libretto articulating socially conservative structures meshes with, and enables, musically progressive expressivity. This essay analyses the opera from a perspective of feminist critique, centering on the title role and providing a close reading of both libretto and score as they play with the erotic and the exotic. The analysis is framed through the lens of the opera's reception in 1889 by way of socio-political readings and of discussions of music's aesthetic capacity for sensual immediacy.

INDEX

Keywords: Jules Massenet, Esclarmonde, sexuality, gender, religion, Wagnerism, exoticism Mots-clés: Jules Massenet, Esclarmonde, sexualité, genre, Wagnérisme, religion, exotisme 